\title{
Sodality in Peri-Urban Community Empowerment: Perspective of Development Communication and Extension Science
}

\section{Sodality dalam Pemberdayaan Masyarakat: Perspektif Ilmu Komunikasi dan Penyuluhan Pembangunan}

\author{
Sumardjo $^{1 *}$, Adi Firmansyah ${ }^{2)}$, Leonard Dharmawan ${ }^{3)}$ \\ ${ }^{1}$ Department of Communication and Community Development Science, Faculty of Human Ecology, IPB University \\ ${ }^{2}$ Center for Alternative Dispute Resolution and Community Empowerment, Institute for Research and Community Service, \\ IPB University \\ ${ }^{3}$ Vocational School, IPB University \\ ${ }^{*}$ Corresponding author: sumardjo@apps.ipb.ac.id
}

Received: April 8, 2021 | Revised: July 1, 2021 | Accepted: July 29, 2021 | Online publication: August 9, 2021

\begin{tabular}{|c|}
\hline ABSTRACT \\
\hline $\begin{array}{l}\text { Tjondronegoro's concept of sodality is gaining momentum to be applied in a broader context. Sodality is relevant to } \\
\text { participatory approaches in community development, extension/empowerment, and development communication. This } \\
\text { study aims to answer how the role of sodality is in the empowerment of peri-urban communities from communication and } \\
\text { extension development sciences. This research method uses a participatory action study by placing the researcher to live } \\
\text { with the community. Sodality can be interpreted as the life force of a unique community unit. However, without any family } \\
\text { relationship, they are bound by a synergy of interest relations without eliminating the primary relationship. In the context } \\
\text { of empowerment, the bonds in sodality are colored more with interest in achieving life necessities among community } \\
\text { members. Thus, in peri-urban communities, sodality is closer to the meaning of social capital, which effectively strengthens } \\
\text { the community's efforts to live a life together, both with internal and external parties. The Tjondronegoro version of the } \\
\text { concept of sodality in the current era is not only for the smallest community unit in the community territory, but it can be } \\
\text { strengthened by the meaning of a synergy of interests in meeting the needs of a community. }\end{array}$ \\
\hline Keywords: empowerment, peri-urban, sodality, social capital \\
\hline ABSTRAK \\
\hline $\begin{array}{l}\text { Pemberdayaan masyarakat semakin penting di dalam pembangunan masyarakat dan konsep sodality buah pikiran } \\
\text { Tjondronegoro mendapatkan momentum untuk diaplikasikan dalam konteks yang lebih luas. Sodality relevan dengan } \\
\text { pendekatan partisipatif dalam pengembangan masyarakat, penyuluhan/ pemberdayaan dan komunikasi pembangunan pada } \\
\text { umumnya. Tujuan penelitian ini ingin menjawab permasalahan tentang bagaimana peran sodality dalam pemberdayaan } \\
\text { masyarakat peri urban dari perspektif ilmu komunikasi dan penyuluhan pembangunan. Metode penelitian ini menggunakan } \\
\text { kaji tindak partisipatif dengan menempatkan peneliti hidup bersama masyarakat. Sodaliti ternyata dapat dimaknai sebagai } \\
\text { daya hidup suatu kesatuan masyarakat yang khas, meski tanpa ada hubungan keluarga namun di antara mereka terikat oleh } \\
\text { sinergi hubungan kepentingan, tanpa menghapus hubungan primer. Dalam konteks pemberdayaan, ikatan dalam sodaliti } \\
\text { lebih diwarnai kepentingan untuk meraih pemenuhan kebutuhan hidup di antara warga masyarakat. Dengan demikian pada } \\
\text { masyarakat peri-urban, sodaliti lebih dekat dengan makna social capital yang efektif memperkuat upaya masyarakat dalam } \\
\text { menjalani kehidupan bersama, baik dengan pihak internal maupun eksternal. Konsep sodality versi Tjondronegoro di era } \\
\text { kekinian tidak hanya untuk kesatuan masyarakat terkecil dalam teritori komunitas, namun dapat diperkuat dengan makna } \\
\text { adanya sinergi kepentingan dalam memenuhi kebutuhan hidup suatu masyarakat. }\end{array}$ \\
\hline Kata kunci: pemberdayaan, peri-urban, sodality, modal sosial \\
\hline
\end{tabular}

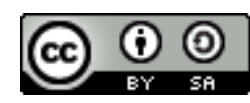

Content from this work may be used under the terms of the Creative Commons Attribution-Share A like 4.0 International. Any further distribution of this work must maintain attribution to the author(s) and the title of the work, journal citation and DOI.

Published under Department of Communication and Community Development Science, IPB University and in association with Ikatan Sosiologi Indonesia

E-ISSN: 2302-7525 | P-ISSN: 2302-7157 


\section{INTRODUCTION}

Changes in society can occur in line with developments in information and communication technology, and changes in the strategic environment, such as the conversion of agricultural land to other uses. These changes primarily occur in rural to peri-urban communities. It is attractive to find out to what extent the peri-urban community is prepared to face changes in the strategic environment and a shift in solidarity among community members. Community empowerment is needed to strengthen community readiness so that it can exist and develop in a changing strategic environment.

Peri-urban society is a transition society from rural to urban characteristics due to shifting strategic environmental conditions and functions (Oroh et al., 2019; Supriyatin et al., 2020). Sodality is the life force of a unique community; they are bound by convergence or synergy of relations of interests. Sodality is related to solidarity among villagers so that they can withstand exposure to socio-economic problems that occur in society (Tjondronegoro, 1984). In the context of empowerment, the bonds in Sodality are colored more with interest in achieving the fulfillment of life necessities among community members. Thus, in peri-urban societies, the concept of sodality is needed, which effectively strengthens the community's efforts to live a life together, both internally and externally.

Rural communities are required to be able to transform into peri-urban communities in line with the development of economic infrastructure and changes in land use to meet their daily needs. Presidential Regulation (Perpres) Number 59 of 2019 concerning Control of Transfer of Land Functions has been issued to control the conversion of land functions for food. The transition from rural and agricultural to urban communities due to shifting land use is known as semi-urban (BPS) or sub-urban or peri-urban communities (Oroh et al., 2019; Supriyatin et al., 2020).

The peri-urban transition society faces the risk of poverty and helplessness if it does not find effective reinforcement of solidarity between them in meeting the needs of living together. Here we need the right empowerment efforts. This study seeks to understand solidarity among communities (sodality) in the face of changes in their strategic environment and to recommend appropriate and effective strategic empowerment efforts as a novelty. Specifically, this study responds to Sajogyo's warning in his writing entitled Modernization without Development in the Journal of Social Studies, which states that development occurs, but there is no increase in productivity (Sajogyo, 1982), and the development of Tjondronegoro's concept of sodality is an alternative solution in community empowerment (Tjondonegoro 1984). This study aims to answer how the role of sodality is in the empowerment of periurban communities from communication and extension development sciences.

\section{Theoretical review}

The participatory approach places the community as the subject in development activities. This approach is a criticism of developmentalism towards the conventional approach to community development which places the community as a party involved (as an object) in development. Participation is a central issue in the implementation of development.

Three basic principles of empowerment programs are: knowledge, action, and awareness (Reason and Bradburry 2012). "Knowledge" is the power to access power in society as a subject because having knowledge can develop social networks in society. Meanwhile, "awareness" can affect the effectiveness of empowerment because community awareness as a subject can determine appropriate empowerment efforts to address gaps and risks of poverty that may occur. 'Knowledge and awareness' will be adequate if it is accompanied by actions that involve the power (social power) of local leaders in the power mechanism, which forms other more significant actions.

Referring to Freire (2003), there are three types of consciousness, namely: (1) magical conscience, namely awareness of the causes of helplessness from external factors, both natural and supernatural. (2) naval conscience, namely the awareness of the human side as the cause of people's powerlessness, (3) critical conscience, namely aspects of the system and structure as the cause of helplessness.

In the perspective of development education and communication in community empowerment, there are eight basics 'social power' in empowerment efforts (Rahman, 2013), namely (1) defensible life space, (2) extra time, (3) knowledge and skills, (4) appropriate information and social organization, (5) social networks, (6) instruments of work, (7) livelihood, and (8) financial resources. This concept emphasizes the household aspect as the smallest unit of society supported by relative access to the wider community. 
This can be facilitated through a communication and extension development approach in community empowerment.

According to Tjondronegoro (1984), development for people's welfare should be oriented to groups based on territorial communities, which can meet the needs of society to form a democratic entity called Sodality. It is namely strengthening solidarity among citizens to survive and rise in the face of changes that occur in society. The empowerment paradigm is human development or people-centered development, which encourages community initiatives.

(Chambers, 2007; Luitel, 2017) Community empowerment is a concept of economic development that summarizes social values that are: (1) people-centered, (2) participatory, (3) empowering, and (4) sustainable. This concept does not merely fulfill basic needs and net safety mechanisms but is an attempt to find alternatives to the old concept of development based on past economic growth.

According to the perspective of development extension (Sumardjo, 2020), community empowerment is basically a process of developing the potential and abilities of individuals/communities to strengthen their capacities and solve the problems they face so that they can meet their daily needs. The ultimate goal of community empowerment is the formation of independent, prosperous, and dignified individuals and communities (Sumardjo et al., 2014; Sulistiyani et al., 2018). This independence includes independence to think, act and control what they do. The main consequence and responsibility in the development program through the empowerment approach are that the community is empowered or has power, strength, or ability. The strength in question can be seen from the physical and material aspects, economics, institutions, cooperation, intellectual strength, and joint commitment in applying the principles of empowerment. According to Sumardjo et al. (2014), the characteristics of empowered citizens are: (1) being able to understand themselves and their potentials; (2) being able to plan (anticipate future changing conditions); (3) being able to direct themselves; (4) having the power to negotiate; (5) having adequate bargaining power in conducting mutually beneficial cooperation; and (6) being responsible for their actions.

In terms of the scope and object of empowerment, it includes several aspects: (1) The ability of individuals and groups to increase ownership of assets (physical and financial resources) and to utilize these assets to improve their lives. (2) The relationship between individuals and groups concerning the ownership of assets and the ability to use them. (3) Empowerment and institutional reform. (4) Network development and work-partnerships, both at the local, regional, and global levels (Sumardjo et al., 2014).

Servaes (2020), a development communication expert, emphasizes the importance of development. For people to grow and lead successful lives, they must adapt to changes in the social, economic, and technological fields. In order for a country to lead its people in growth and development, information and knowledge about these changes must be made available to them on a priority basis. He points out that all of the above cannot be achieved without proper utilization of all communication methods. In the context of empowerment (Hentihu et al., 2020; Sumardjo et al., 2020) their research concluded that the participatory communication paradigm that prioritizes dialogue leads to the impact of mutual understanding, mutual agreement, and collective action among participants according to their respective portions.

\section{METHOD}

This study uses the interpretism or constructivism paradigm that is related to the interpretation, giving meaning to individual experiences, which are seen as a whole, holistic, gestalt and includes the meaning contained in the object (Hennink et al., 2020) Researchers seek to understand and explain meaningful social actions.

The study method used is a qualitative method (Denzin et al., 2018) with a participatory action research approach, namely by placing field researchers as facilitators of community empowerment.

The primary analysis technique is based on the cybernetic analysis approach, the dialectic between the results of interviews, FGDs, participating observations, and using the theoretical framework referred to in the framework to discuss. The data used are mainly primary, original (factual and objective), and updated data for the last three years. 
Data and information were collected through observation, in-depth interviews with informants using interview guidelines (open questions), field notes, and focus group discussions (FGDs). Secondary data were obtained from literature reviews and documents from related agencies. Activity data on the empowerment of coastal communities and the phenomena have become the background for the behavior and participation of coastal communities. Empowerment is analyzed from the results of observations and in-depth interviews during the research process. The analysis results were discussed in an FGD involving related parties who were considered to have understood or been influential in the community empowerment process to obtain objectivity on the related facts.

The main informants of the study were 15 people, including the following figures: Village Head, Chair of the Seaweed Cooperative, Community Leaders (BPD), seaweed farmer figures from both villages, empowerment facilitators, company CSR staff, CARE LPPM IPB (representing universities high) and cooperative partner figures.

The research locations were in two villages, namely Tambaksari Village and Sedaris Village, Karawang. The data analysis technique used a qualitative research paradigm through participatory action research with a cybernetics approach (triangulation). The provisional findings were discussed in focus group discussions with community leaders, representatives of coastal communities participants, field researchers, and empowering facilitators (Hennink et al., 2020). The unit of analysis is the seaweed business entity in the people's ponds in the two villages. The location was chosen for this research based on the consideration of the transitional coastal rural communities that have been exposed to a broad market (peri-urban community) when the research was carried out in 2019-2020 by placing field researchers and deepened in February-March 2021.

This research is basically in one village, but it is divided into two villages in extracting information from informants and observations. Sociality extends to other villages at the cooperative level. The analysis of this study is not intended to compare the two villages for widespread social capital and social capital, which are more based on economic interests.

\section{RESULTS AND DISCUSSION}

\section{Characteristics of peri-urban communities in empowering seaweed businesses}

Tambaksari Village is a peri-urban village, transitioning from traditional milkfish farmers to seaweed and milkfish polyculture, which serve industrial raw materials and urban communities' consumption. This village is a coastal community located in Tirtajaya District, Karawang Regency, West Java Province, as a peri-urban transitional village. There is an increase in IDM 2015 from 0.5497 as a disadvantaged village (Kemendesa 2016) to 0.6251 in 2019 as a developing village (Kemendesa 2020). The IDM value illustrates the development of social, economic, and ecological aspects.

In terms of education, the population in this village is categorized as low (elementary school graduates and not elementary school graduates), namely 57.1 percent, 36.1 percent secondary education (SMP and SMA), and 6.8 percent higher education (diploma and above). This illustration explains that, in general, the population in Tambaksari Village has not fulfilled the 12-year compulsory education.

The farmer community in this study is a community of farmers who work on forestry land (Perhutani). Based on the interview results, the number of Perhutani farmers in Tambaksari Village is quite large, considering that 60 percent of the land in this village is included in the forest area managed by Perhutani. Some of the farmers are organized in a farmer cooperative, which is called the Mina Agar Makmur Cooperative (KMAM). One of the communities in Tambaksari Village is a community of land cultivators. This community is quite large because most of the population uses Perhutani's land, which amounts to around 60 percent of the land in this village.

People in Tambaksari Village generally work as farmers, 75 percent of whom work on Perhutani's land by paying a fee of Three hundred thousand rupiahs per year, and the rest outside Perhutani, with average one hectare of cultivated land. A coastal community that cultivates this land has an open culture and tends to trust immigrants, let alone fellow residents. 


\section{Sodality in the sustainability of seaweed cooperatives}

The aspect of community solidarity (sodality) is reflected in the economic institutions in Tambaksari Village, which are closely related to coastal communities' livelihoods. There seems to be a shift in sodality from being based on village territory to being based on the interests of fulfilling the needs of life in the form of economic institutions, namely the Mina Agar Makmur Cooperative.

The farmer community cooperative survives and develops because of the solidarity bond among the villagers. Even apart from the members, it has more than 400 partners spread across Karawang, Bekasi, Subang, and Indramayu. This illustrates that sodality, which is based on territory (sodality), can expand when the bond of solidarity also includes common interests in meeting the needs of life, especially the economy. In this case, sodality develops into a form of social capital that binds internally and externally based on the cohesiveness of the interests of fulfilling the broader needs of life and relationships that are not primary in nature.

Internally, the solidarity of the community is strengthened. As reflected in the increase in participation and the increase in the number of active members, in 2016, there were 26 members, and in 2018 there were 72 people, and in 2020 there were around 100 community members who joined as members from across villages. Externally there is a partnership relationship with outsiders, even from three other districts. In this case, community solidarity is strengthened by indications of strengthening social capital. The development of internal community solidarity (sodality) strengthens internal and external community solidarity (social capital), showing cooperative wealth performance as shown in the Table 1.

Table 1 Wealth Growth of KMAM cooperatives in 2016-2020

\begin{tabular}{rlc}
\hline No. & \multicolumn{1}{c}{ Description } & Average of Growth 2016-2020 (\%) \\
\hline 1. & Main Savings & 16,46 \\
2. & compulsory Savings & 154,42 \\
3. & Other Savings & 36,30 \\
6. & Operating Reserves & 34,97 \\
\hline \multicolumn{2}{l}{ Means } & 90,96 \\
\hline
\end{tabular}

This cooperative runs a business in order to serve the needs of its members and the community. The following are the efforts carried out by cooperation (KMAM): (1) purchasing the member's seaweed cultivation, (2) selling cultivated seaweed to cooperative partner factories, (3) providing seaweed cultivation production facilities, (4) selling bulk ice to members of fish traders, (5) purchasing fish feed from members, (6) purchasing seaweed and milkfish seeds, and (7) providing facilities to support members' business activities.

Community solidarity in the cooperative institution is strengthened by implementing a work program involving the community members of the cooperative. These programs are programs related to social programs, which involve the community or members. These programs are routinely carried out every year. The following programs are carried out by the cooperative: (1) "Bridge" that caring cooperatives, (2) Training to improve the quality of partner's seaweed, (3) Cooperative evaluation meetings, and (4) Training on polyculture cultivation of seaweed, milkfish, and tiger prawns.

\section{Sodality in coastal community empowerment}

Community empowerment in Tambaksari Village occurs through developing the potential and capacity of individuals/communities so that their capacities are strengthened in meeting the needs of the community. Activities carried out by the community can overcome the problems they face to meet their daily needs. This empowerment activity's impact is reflected in the formation of independent, prosperous, and dignified individuals and communities. This is in line with Sumardjo et al. (2014) 's findings in several villages in Pantura, West Java, Wahyuni et al., (2017) in West Java, Sulistiyani et al. (2018) in urban community of Papua, and Sumardjo et al., (2020).

Through the role of local figures who act as local champions and in the community empowerment mechanism by means of deliberation and dialogical communication among community members who 
are elected to be the chairman of cooperatives, secretaries, and member bodies of the supervisory body, it is evident that it is effective in the development of community solidarity (sodality). In addition to internal solidarity, it also extends to strengthening external solidarity. This happens because of the strengthening of social capital in the community empowerment process.

According to one of the facilitators independence is reflected in the figure of community leaders who show an anticipatory attitude in making cooperative decisions.

"Community leaders in making decisions consider input from members, the community, and cooperative partners. Moreover, the community believes in him as a manager and reminds the cooperative manager when things occur that have the potential to pose a risk to the common interest. This mutual trust is what seems to make the cooperative thrive-for example, conveying thoughts to the manager to determine the quality grades of seaweed is done transparently, each with a reasonable price. Moreover, the proposal is implemented by the manager. " (D, 25 years old: Empowering Facilitator)

The facilitator's opinion illustrates that independence is reflected in the independence of thinking, acting, and controlling what they do. Community power is also reflected in the physical and material aspects, economy, institution, cooperation, intellectual strength, and joint commitment in applying the principles of empowerment. This is in line with the characteristics of empowered citizens, namely: (1) being able to understand themselves and their potentials (Dharmawan, et al., 2019), (2) being able to plan (anticipate future changing conditions); (3) being able to direct themselves, (4) having the power to negotiate, (5) having adequate bargaining power in conducting mutually beneficial cooperation (Dharmawan, et al., 2020), and (6) being responsible for their actions (Sumardjo, 2010).

In the empowerment program for farmers in the research location, there are at least three efforts, namely: (1) Institutional development through community organizing, (2) Capacity building for farmers, and (3) Network development. In community organizing, there is an area of public space for dialogue to discuss and make decisions on existing and potential problems. The impact is that people can find resources that they can use. In community empowerment, farmer groups are formed as a forum for reflection and joint action with community members.

In line with the development of cooperative businesses, three groups were formed in a participatory manner, namely (1) the Anugrah Pertiwi group, which processes seaweed processing, (2) the Bumi Kreatif Agar Makmur group, which processes seaweed waste into feed, and (3) the C73 group which processing milkfish. The existence of these groups strengthens the cooperative's efforts and at the same time accommodates the businesses of members. The development of cooperatives can be seen in Figure 1 regarding the information on community organizing by cooperatives.

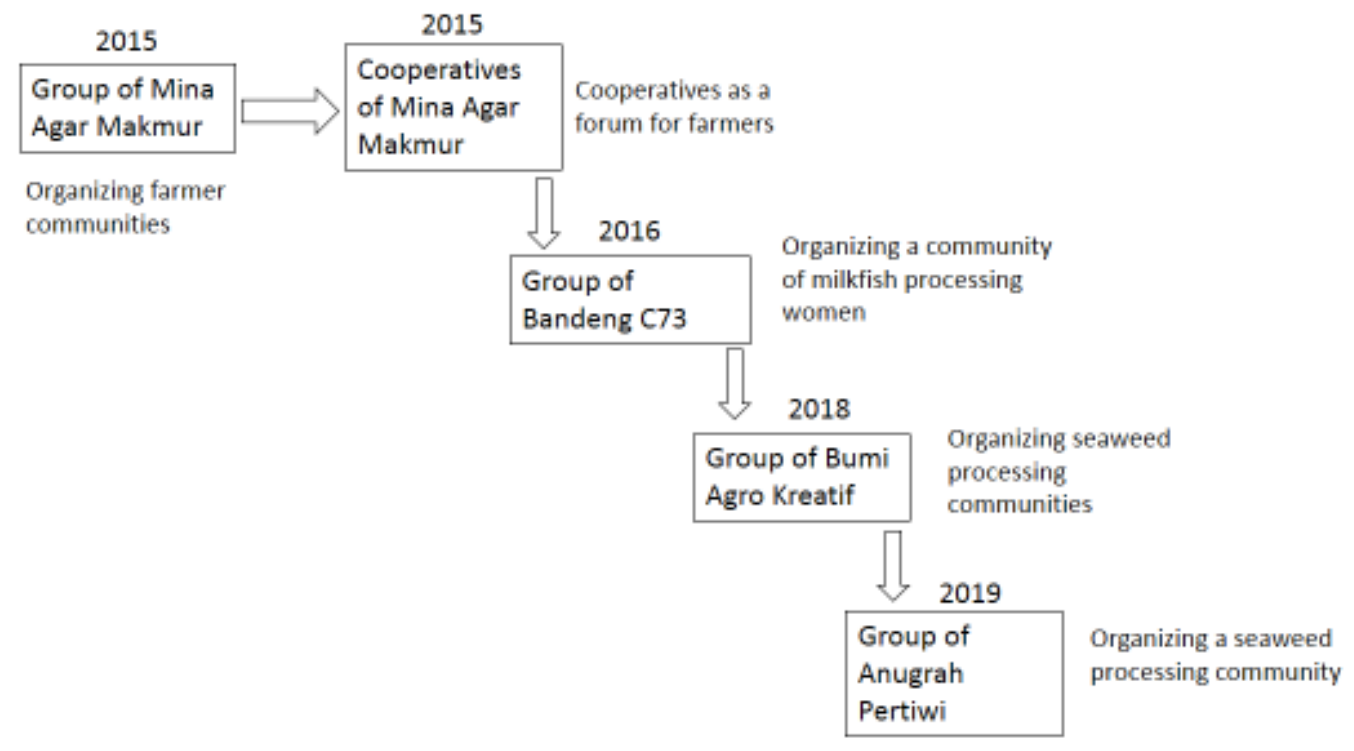

Figure 1. Community organizing through KMAM cooperatives 
Cooperatives are a manifestation of sodality that strengthens internal and external solidarity driven by local figures by strengthening individuals and groups. This is in line with the opinion of Tjondronegoro (1984) and Pettit \& McGee (2019). Strengthening individuals' capacity in coastal communities occurs by increasing knowledge about seaweed cultivation and processing, waste utilization, and milkfish processing, which are household businesses for coastal communities. Strengthening individual capacity is in line with strengthening social capital that occurs in society. An illustration of the strengthening of social capital can be seen in Figure 2.

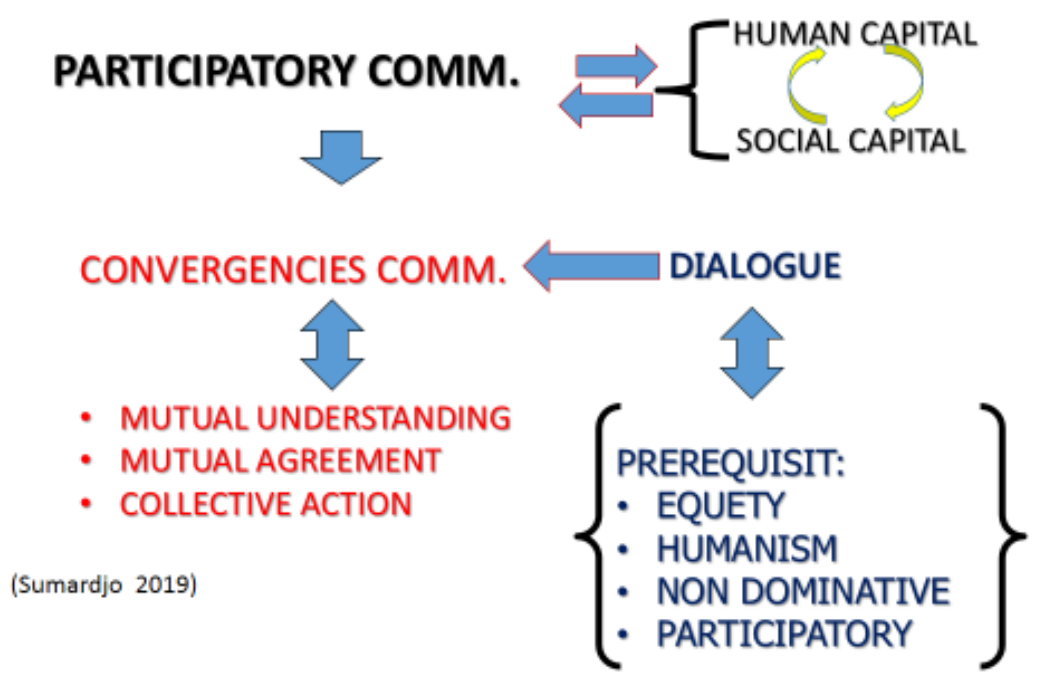

Figure 2. Participatory Communication: Convergencies and Dialogue Prerequisit

Social capital is built through a participatory communication process that effectively builds the community's individuality (human capital). Communication that occurs in dialogue causes convergence among community members who are members of the cooperative, in the form of mutual understanding, mutual agreement, and collective action in three groups that have different roles as described above. Dialogue among the community is effective because of mutual respect between members, leader and management (participatory, equity, humanism, and non-dominative as dialogue prerequisit).

Network development is carried out by collaborating with other parties (individuals, groups, and organizations) so that awareness, attitudes, and actions are supported by the knowledge of the importance of supporting each other to meet society's needs. This is reflected in polyculture cultivation which the community considers getting beneficial. The network that was built with mutual trust turned out to be an essential element of social capital, thus becoming an essential component in community empowerment. This can be seen from the following statements by community leaders.

"The community believes in cooperatives; it can be seen from the efforts to develop polyculture ponds. The advantages of polyculture ponds actually increase farmers' income because they get the harvest from two or three commodities. The cultivation cycle for these three commodities is different. The cycle for cultivated milkfish is 6-7 months, shrimp is cultivated for four months, and seaweed is cultivated for 4-5 months. The type of seaweed that is cultivated is Gracilaria Sp, with good maintenance time in the range of December - March. Each cultivator at harvest can produce 3-5 tons of wet seaweed, which is then dried into two tons of dry seaweed. Polyculture organic pond system can also provide ecological benefits in the form of absorption of pond contamination by seaweed so that the quality of pond water will be better and the pond area's environmental conditions will be preserved. Another prevention of environmental degradation is the cultivation of seaweed in cooperative members that do not use harmful substances for humans, such as drugs to eradicate pests. " (U, 55 years old: Community Leader).

External cohesiveness between the community and outsiders can be seen from the network of cooperation and partnerships that occur between cooperatives and related parties, as shown in Figure 3. According to the observation of the Chairman of the Cooperative, cooperatives are pretty successful in building cooperation with various parties/agencies, including academics, companies, government, and the community. From the academic side, the cooperative collaborates with the Karawang College of 
Fisheries Sciences (STIP) in student research collaboration on commodities developed by the cooperative. Until now, more than ten students have conducted research in cooperative locations.

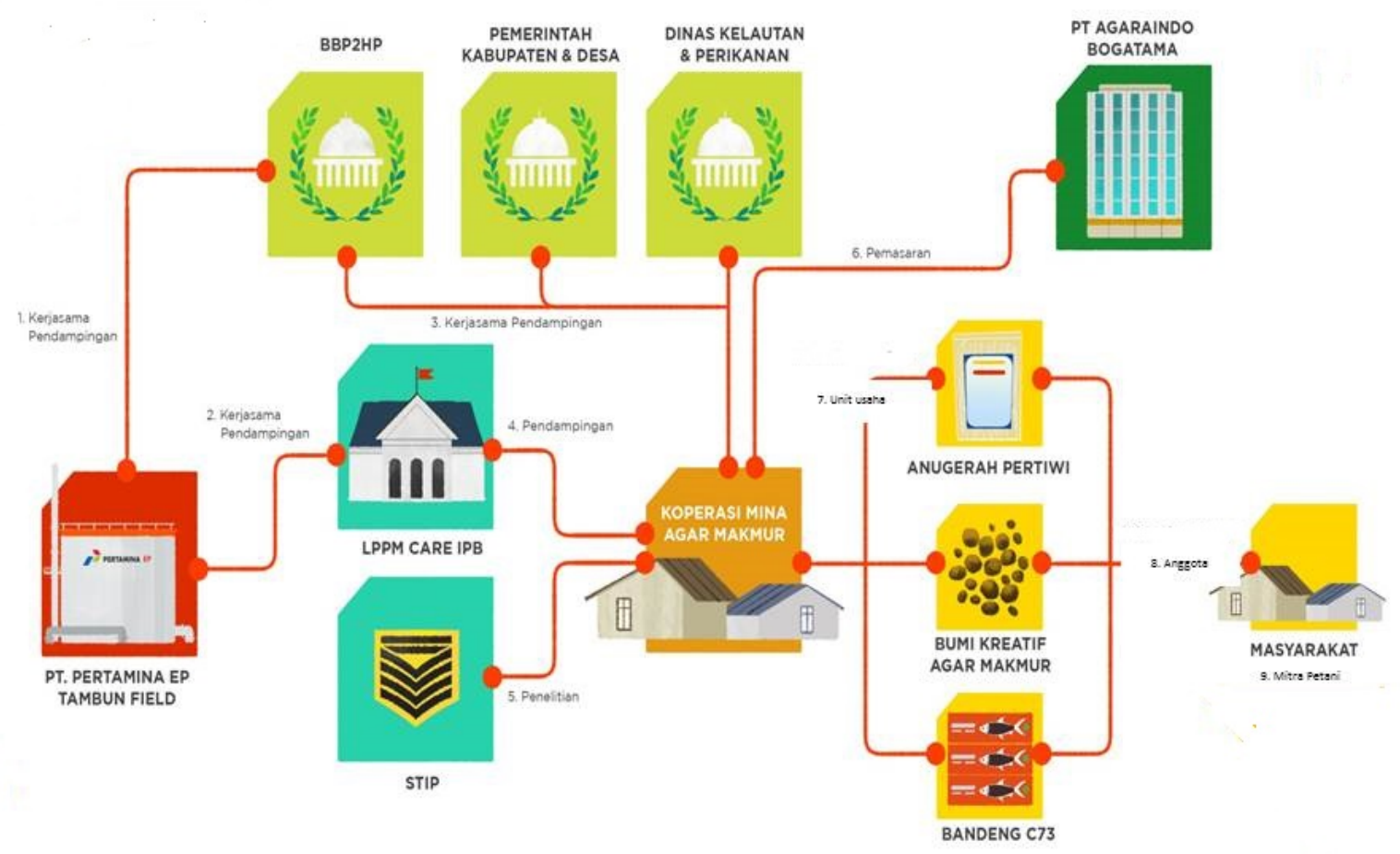

Figure 3. Partnership networks built by cooperatives

\section{Sodality and Social Capital}

The cooperative partners with companies, namely PT. Pertamina EP Tambun Field and PT. Agarindo Bogatama. Collaboration with PT. Pertamina EP Tambun Filed is carried out in the form of mentoring, capacity building for cooperative members, and assistance for production infrastructure. Partnerships were also established with PT. Agarindo Bogatama as a seaweed sales partner. All the seaweed that is harvested by the community is then sold to PT. Agarindo Bogatama. The cooperative is also partnering with the Center for Testing the Application of Fishery Products (BBP2HP) related to processed seaweed products' innovation. BBP2HP provides training to cooperative members on how to process seaweed into agar strips and crystal noodles. Currently, processed seaweed products "Agar Strip" have started to be commercialized through online marketing channels or social media. The cooperative has also partnered with the Center for Conflict Resolution Studies (CARE) LPPM IPB University concerning placing field companion scholars for IPB alumni. CARE LPPM IPB also conducts routine monitoring every three months in dialogue to discuss cooperative problems.

Almost all cooperatives' cooperation with their partners is based on trust capital and is often not accompanied by a written agreement. This trust is a cooperative social capital that can encourage social collaboration to achieve common interests and goals (Coleman, 1988; Sumardjo et al., 2014). The success of cooperatives in establishing various partnerships cannot be separated from the cooperative chairman's capacity, who has an extensive network. The leader becomes the entrance to empowerment, namely as a liaison between farmer groups and related parties and as a bridge for necessary information entry. That is in line with previous research (Mutmainah and Sumardjo, 2014; Martin et al. 2016; Kerrigan et al., 2015) that leaders have an essential role in developing groups and influencing their members to be involved in empowerment activities.

In this study, the farmer community's social capital in Tambaksari Village is seen from community networks, spirituality/belief system, mutual cooperation culture, agreed and obeyed norms and values system, level of trust among residents. The image of the social capital of the community in cooperating can be seen in Table 2. Based on Table 2, it can be seen that this community's social capital is quite good. What seems to have the potential to weaken sodality among community members is the aspect of togetherness in the form of mutual cooperation, which is fading along with the lack of selectivity in 
establishing a wider network of cooperation. In this case, the weakening of sodality is in line with the weakening of social capital elements.

Table 2 Social capital of the farmer community in Tambaksari Village, 2019

\begin{tabular}{ll}
\hline \multicolumn{1}{c}{ Indicator } & \multicolumn{1}{c}{ Description } \\
\hline Community networks & $\begin{array}{l}\text { Community networks reach district level. This is thanks to the existence } \\
\text { of the Agar Makmur Cooperative which is known to the district level and } \\
\text { even more }\end{array}$ \\
$\begin{array}{l}\text { Spiritualism / belief } \\
\text { system }\end{array}$ & $\begin{array}{l}\text { The capital of spiritualism cannot be separated from the religion adhered } \\
\text { to by most of the Tambaksari community, namely Islam. Generally, the } \\
\text { Tambaksari people are devout Muslims. }\end{array}$ \\
$\begin{array}{l}\text { Mutual cooperation } \\
\text { culture }\end{array}$ & $\begin{array}{l}\text { The culture of mutual cooperation in this village has tended to fade. } \\
\text { A system of norms and } \\
\text { values that are agreed }\end{array}$ \\
$\begin{array}{l}\text { There is a system of agreed norms and values, but some obey and some } \\
\text { do not comply }\end{array}$ \\
$\begin{array}{l}\text { Tambaksari Village is a community with a coastal culture. One of the } \\
\text { residents }\end{array}$
\end{tabular}

\section{The development of sodality}

Based on the description of the research findings described, the following lessons can be drawn. Efforts to strengthen sodality (Tjondronegoro 1984) in empowering coastal communities require strengthening the capacity of individuals, community groups, and community institutions (Servaes, 2020). The application of concepts related to social capital is considered to be the right momentum. Social capital, referred to here, is basically a value of the mutual trust between members of society, between society and its leaders, and with other societies (Hilgers \& Mangez, 2014; Fukuyama and Picador, 2018; Coleman, 1988; Sumardjo et al., 2014). Social capital is also a social institution that involves networks, norms, and social trust that encourage social collaboration (coordination and cooperation) to achieve related parties' interests and goals. In line with Sumardjo (2010), strengthening social capital requires strengthening human capital, and strengthening human capital is the result of community empowerment efforts or development counseling/communication. It means that the community empowerment approach by strengthening social and human capital is the right way to implement a strategic plan that has been formulated in a participatory manner by the coastal communities of the North Coast of Karawang.

This picture implies that sodality can develop in the current era by strengthening social capital and strengthening community members' individuality (human capital), especially the leader. From the perspective of development education and communication, the development of sodality can be pursued by increasing individuals' ability (human capital) to optimize manage community capital which includes human capital, social capital, natural capital, and economic capital optimally.

In Figure 4, it can be seen how the sodality is strengthened. Apart from internal cohesiveness in the form of an interest in fulfilling the needs of life among the community, it is also internal cohesiveness in the form of a convergence of the interests of outsiders with community members' interests. Sodality develops into internal and external solidarity based on the formation and strengthening of social capital between the internal and external entities. 


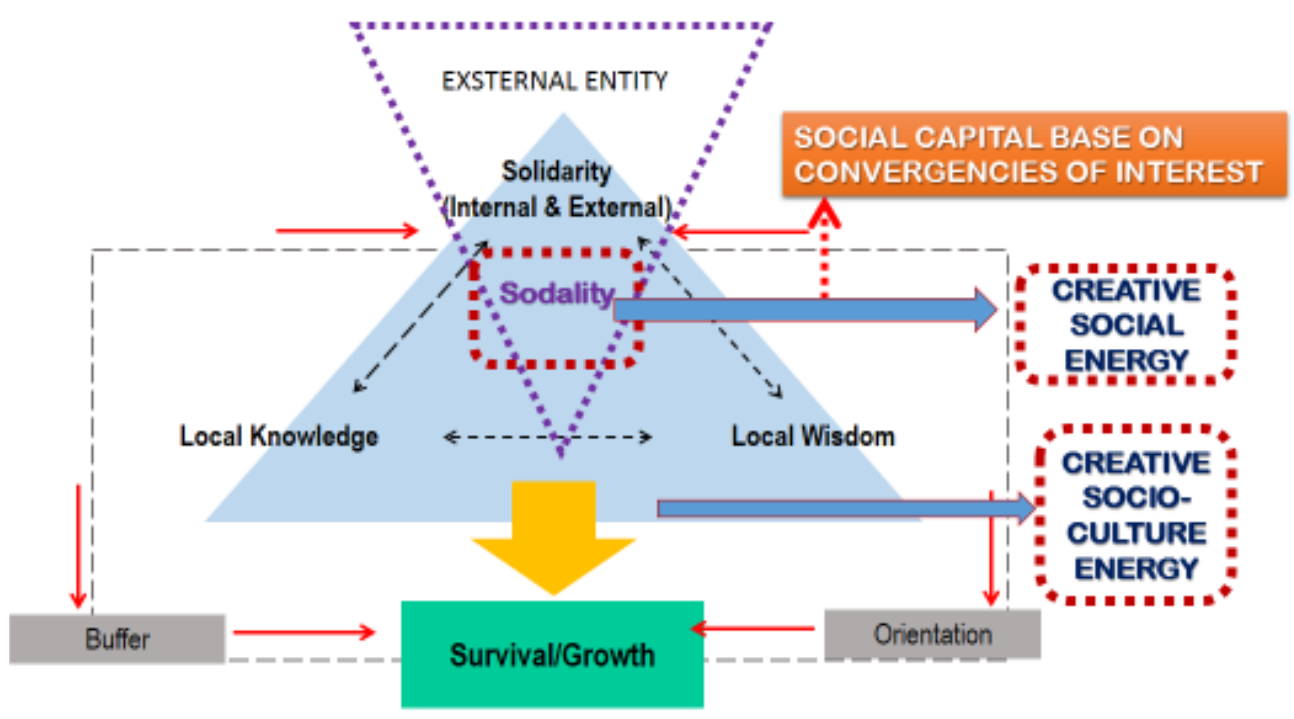

Figure 4. The deveplopement of sodality occurs based on social capital and social energy

The form of strengthening sodality is the creative social energy that is in line with time, the creative socio-cultural energy. This creative social energy includes the convergence of related parties' interests in terms of ideals, ideas, and friendships. The ideal is the best condition that is wanted to be realized together among empowerment participants (related parties), and the ideas are ways to realize the ideal, while the friendships are the selection of potential parties who deserve to have collaborated as synergistic partners. If the social, creative energy that is built up functions in a sustainable manner, then this is known as the creative socio-cultural energy or the internal strength of a cultured society (Upphof, 1986; Sumardjo et al., 2020).

The development of creative social energy in community empowerment, according to Sumardjo (2010) and Sumardjo et al., (2014), will also reflect the strengthening of the characteristics of an empowered society, both in terms of individual capacity (human capital) and from the scope and aspects of empowerment. Such community empowerment is an implementation of the concept of economic development, which summarizes social values that are: (1) people-centered, (2) participatory, (3) empowering, and (4) sustainable, as expressed by Chambers (2007). From the perspective of development extension and communication, a lesson has also been drawn that community empowerment is effective if you pay attention to strengthening the eight bases of social power, which emphasize the aspect of the household as the smallest unit supported by access to the broader community as happened to cooperatives in Tambaksari Village, namely: (1) defensible life space, (2) extra time, (3) knowledge and skills, (4) appropriate information and social organization, (5) social networks, (6) instruments of work, (7) livelihood, and (8) financial resources. This can be seen from the results of interviews with community empowerment facilitators who have assisted the cooperative and lived with the community for the last three years in Tambaksari Village, as follows.

"The life of the fish pond community has ample opportunity to be developed with the existence of a cooperative. These developments include; The community can take advantage of seaweed waste, processing seaweed products, and processing milkfish products outside of their primary job as a farmer. The pond polyculture innovation was obtained from Mr. Usup. He is a local leader, while the innovation related to seaweed processing and seaweed waste processing for milkfish feed was obtained from the Center for Fisheries (BB2HP). Community facilitators facilitate organizational development; he also expands networks that are considered to be able to work synergistically with cooperative businesses. Pertamina EP as a partner supports feed processing machines for pond milkfish to increase the added value of seaweed waste. The livelihoods that were previously used monoculture ponds shifted to polyculture ponds, which gives a higher added value to the farming business. The community also receives facilities from cooperatives, especially those related to capital accumulation and marketing of products. (D, 25 years old, Empowering Facilitator). 
In community empowerment, it seems that the ability to build the three awareness raised by Freire (2003) is needed, namely: awareness of the causes of helplessness from external factors, both natural and supernatural; awareness of the human side as the cause of people's powerlessness; and awareness of system and structure aspects as causes of powerlessness.

Likewise, Hayward $(1998 ; 2018)$ conveyed the power relationship between the powerful and the weak. In this study, it turns out that it can be overcome with an empowerment approach that prioritizes participatory and convergent communication. This is an empowerment approach from the perspective of development extension and communication.

\section{CONCLUSION}

In fact, sodality can be interpreted as the life force of a unique community unit. They are bound by a synergy of interest relations without any family relationship, without eliminating, and the primary relationship. In the context of empowerment, the bonds in sodality are colored more with interest in achieving the fulfillment of life necessities among community members. Thus in peri-urban communities, sodality is closer to the meaning of social capital, which effectively strengthens the community's efforts to live a life together, both with internal and external parties. The Tjondronegoro version of the concept of sodality in the present era is not only for the community territory's smallest community unit, but it can be strengthened by the meaning of a synergy of interests in meeting a community's needs.

The study implies that in peri-urban coastal communities with fishpond as the main activity, social capitalism is found, as stated by Tjondronegoro, but it turns out that with a social capital mindset/perspective, sodality develops from the community level to the outer village level with cohesiveness, widespread trust, and synergy of economic interests.

\section{ACKNOWLEDGEMENT}

Our sincere gratitude is directed to the following:

1. Ministry of Research and Technology/National Agency for Research and Innovation (Kemenristek/BRIN) for research funding facilitation.

2. Pertamina EP for program implementation funding.

3. CARE LPPM IPB University and LPPM IPB for facilitating research implementation.

4. KMAM cooperatives of Tambaksari Village, Karawang.

\section{REFERENCES}

Chambers, R. (2007). Participation and poverty. Development, 50(2). https://doi.org/10.1057/palgrave.development.1100382

Coleman, J.S. 1999. Social Capital in the Creation of Human Capital. Cambridge Mass: Harvad. University Press. Cox, E. 1995. A Truly Civil Society. ABC Books. Sidney.

Denzin, N. K., \& Lincoln, Yvonna, S. (2018). Introduction: The Discipline and Practice of Qualitative Research. In The Sage Handbook of Qualitative Research.

Dharmawan, L., Firmansyah, A., \& Susanto, T. (2019). Komunikasi Inovasi dalam Pemanfaatan Lahan Pekarangan Komunitas Petani untuk Mewujudkan Kemandirian Pangan di Era Digital. Jurnal Komunikasi Pembangunan, 17(1), 55-68. https://doi.org/10.46937/17201926590

Dharmawan, L., Muljono, P., Retno Hapsari, D., \& Priyo Purwanto, B. (2020). Digital Information Development in Agriculture Extension in Facing New Normal Era During Covid-19 Pandemics. Jonuns.Com, 47(12). http://jonuns.com/index.php/journal/article/view/482

Freire, P. (2003). Pendidikan Kaum Tertindas, terj. Lembaga Penelitian Pendidikan dan Penerangan Ekonomi dan Sosial (LP3ES), Bandung: LP3ES 
Fukuyama, F. And Picador. (2018). Identity: The Demand For Dignity And The Politics Of Resentment. Farrar, Straus and Giroux. New York.

Hentihu, I., Sumardjo, Sugihen, B. G., \& Susanto, D. (2020). The Potential for Creative Socio-cultural Energy of Coastal Communities in the Maluku Islands. Asian Research Journal of Arts \& Social Sciences. https://doi.org/10.9734/arjass/2020/v11i330173

Hennink, M., I. Hutter, A. Bailey. (2020). Qualitative Research Methods. Second Edition. SAGE Publication Ltd. Thousand Oaks, USA.

Hilgers, M., E. Mangez (2014). Bourdieu's Theory of Social Fields: Concepts and Applications. London: Routledge

[KEMENDESA] Kementerian Desa, Pembangunan Daerah Tertinggal dan Transmigrasi, 2019. Indeks Desa Membangun 2019 [internet]. [diunduh 2020 Februari 28]. Tersedia pada: http://idm.kemendesa.go.id/

[KEMENDESA] Kementerian Desa, Pembangunan Daerah Tertinggal dan Transmigrasi, 2016. Indeks Desa Membangun 2015. Jakarta (ID): Kemendesa.

Kerrigan, D., Kennedy, C.E., Morgan-Thomas, R., Reza-Paul, S., Mwangi, P., Win, K.T., McFall, A., Fonner, V.A., Butler, J. (2015). A community empowerment approach to the HIV response among sex workers: Effectiveness, challenges, and considerations for implementation and scaleup (Review). The Lancet. Volume 385, Issue 9963, 10 January 2015, Pages 172-185.

Kislev, E. (2020a). "Social Capital, Happiness, and the Unmarried: a Multilevel Analysis of 32 European Countries". Applied Research in Quality of Life. 15 (5): 1475 1492. doi:10.1007/s11482-019-09751-y.

Kislev, E. (2020b). "How do relationship desire and sociability relate to each other among singles? Longitudinal analysis of the Pairfam survey". Journal of Social and Personal Relationships. 37 (8-9): 2634-2650. doi:10.1177/0265407520933000. S2CID 220672728.

Luitel, Y. R. (2017). Participatory Research and Empowerment: A Conceptual Revisit of the Debate on Alternative Social Science Research. Dhaulagiri Journal of Sociology and Anthropology, 11. https://doi.org/10.3126/dsaj.v11i0.18825

Martin, R., Guillaume, Y., Thomas, G., Lee, A. Epitropaki, O. (2016). Leader-Member Exchange (LMX) and Performance: A Meta-Analytic Review(Article). Journal of Personnel Psychology. Vol. 69, Issue 1. Spring 2016, Pages 67-121.

Mutmainah R, Sumardjo. (2014). Peran Kepemimpinan Kelompok Tani dan Efektivitas Pemberdayaan Petani. Sodality: Jurnal Sosiologi Pedesaan [internet]. [diunduh 2020 Februari 16]; 2 (3): 182199: Bogor (ID). Tersedia pada: https://journal.ipb.ac.id/index.php/sodality/article/view/9425/7388.

Oroh A, Kumurur VA, Warouw F. (2019). Analisis Karakteristik Wilayah Peri Urban Berdasarkan Aspek Fisik Di Kecamatan Pineleng Kabupaten Minahasa. Jurnal Spasial Vol 6. No. 2.

Pettit, J., \& McGee, R. (2019). Introduction: power, empowerment and social change. In Power, Empowerment and Social Change. https://doi.org/10.4324/9781351272322-1

Rahman, A. (2013). Women's Empowerment: Concept and Beyond. Global Journal Og Human Social Science. Sociology \& Culture, 13(6), 9-14. https://globaljournals.org/GJHSS_Volume13/2Womens-Empowerment-Concept.pdf

Reason, P. and H. Bradbury (2012) Handbook of Action Research: Participative Inquiry and Practice, London: Sage Publications.

Sajogyo. (1982). Modernization without Development. The Journal of Social Studies.

Servaes J. (2020). Handbook of Communication for Development and Social Change. Springer. Singapore.

Sulistiani I, Sumardjo, Purnaningsih N. (2018). Model and Communication Strategy Development in Developing Social Energy for Papua Community Empowerment. Medwell Journals: The Social Science. 13 (4): 934-942. 
Sumardjo, S., Firmansyah, A., \& Manikharda, S. (2020). Organic Medical Plants Urban Farming Based on Family Empowerment on Bekasi, West Java. Journal of Hunan University, 47(12).

Sumardjo, S., Firmansyah, A., \& Dharmawan, L. (2020). The Role of Creative Social Energy in Strengthening Ecological Adaptation Capacity Through Community Empowerment. Jurnal Penyuluhan, 16(2), 323-332. https://doi.org/10.25015/16202028361

Sumardjo, A. Firmansyah, L. Dharmawan, Y. P Wulandari. (2014). Implementasi CSR Melalui Program Pengembangan Masyarakat: Inovasi Pemberdayaan Masyarakat PT. Pertamina EP Asset 3 Subang Field. CARE LPPM IPB. Bogor.

Supriyatin, R., Pravitasari, A. E., \& Pribadi, D. O. (2020). Pemetaan Karakteristik Wilayah Urban Dan Rural Di Wilayah Bandung Raya Dengan Metode Spatial Clustering. Jurnal Geografi, 12(02). https://doi.org/10.24114/jg.v12i02.17647

Tjondronegoro, Sediono M.P. (1984). Social Organization and Planned Development in Rutal Java. Oxford University Press, Singapore.

Uphoff N. (1986). Local institutional development: An analytical sourcebook with cases Norman Uphoff for the Rural Development Committee, Cornell University Kumarian Press W. Hartford, Connecticut, 1986, $421 \mathrm{pp}$.

Wahyuni, S., Sumardjo, S., Lubis, D. P., \& Sadono, D. (2017). Hubungan Jaringan Komunikasi dan Dinamika Kelompok dengan Kapasitas Petani dalam Agribisnis Padi Organik di Jawa Barat. Jurnal Penyuluhan, 13(1), 110-120. https://doi.org/10.25015/penyuluhan.v13i1.15115. 